\title{
PRELIMINARY REPORT TO THE EDITION OF EDWARD SAPIR'S COMPARATIVE DICTIONARY OF INDO-CHINESE AND NA-DENE
}

\author{
Keywords: E. Sapir, Na-Dene languages, Indo-Chinese, distant relationship of languages, \\ postulation of macrofamily
}

\begin{abstract}
In the report the author explains his aspired project of the edition of Edward Sapir's Comparative dictionary of Indo-Chinese and $\mathrm{Na}$-Dene, kept as a manuscript in the Franz Boas estate in the library of the American Philosophical Society in Philadelphia. The manuscript forms one volume of Sapir's Comparative dictionary of $\mathrm{Na-Dene} \mathrm{languages.}$
\end{abstract}

The subject matter of the present report is the author's aspired edition project of the manuscript of the Comparative dictionary of Indo-Chinese and Na-Dene written by Edward Sapir and left by his teacher, the late Franz Boas, currently kept in the Boas estate in the library of the American Philosophical Society, Philadelphia.

It is widely accepted that Sapir coined the term $\mathrm{Na}$-Dene in his famous article "The Na-Dene languages. A preliminary report" from 1915. In that paper ${ }^{1}$ he purposed and (re-)constructed common Athapaskan forms for the first time and in this way "proved" the already recognized genetic relationship of the Na-Dene languages (including Haida and omitting Eyak). However, less known is Sapir's research regarding the investigations of distant and external relationships of the Na-Dene languages. ${ }^{2}$ Sapir not only postulated the relations of the Na-Dene languages and "Indo-Chinese" (= Sino-Tibetan + Thai) based on some highly speculative contributions of various

1 Strictly speaking, historical and comparative linguistics do not know "re-constructions", but constructions only.

2 So far only Kaye (1992) has dealt with Sapir's comparative studies on distant relationships. 
authors as well as on scattered notes in the works from the $19^{\text {th }}$ and early $20^{\text {th }}$ centuries, but also compiled the results of his studies on this topic in the shape of a comparative dictionary. Till now nearly no attention has been paid to this dictionary - not even by various omnicomparativists working in this field. ${ }^{3}$

As mentioned above, the dictionary material is today kept in the "Franz Boas Collection of Materials for American Linguistics" in the library of the American Philosophical Society (APS) in Philadelphia. The Sino-Tibetan-Na-Denean comparative dictionary, that was written around 1920 and forms the second volume of Sapir's four-volume hand- and type-written Comparative $\mathrm{Na}$-Dene dictionary, ${ }^{4}$ is stored in the library with the shelf mark "AMs, $4 \mathrm{v} \mathrm{Na} 20 \mathrm{a} .3$ ". ${ }^{5}$ In this Comparative dictionary of Indo-Chinese and Na-Dene, ${ }^{6}$ which comprises more than 500 card files, forms of various Sino-Tibetan languages are given in one column and compared with their "equivalents" from Na-Dene languages in a second column. In this comparison three major groups were assumed as the Sino-Tibetan languages (Sapir only used the designation "Indo-Chinese"). The term "Sino-Tibétain" was introduced by Jean Przyluski in 1924 and spread to become known by Shafer in 1952 (or a bit earlier): Chinese, Siamese and Tibetan (each comprising directly related languages, i.e. Sinitic languages, Tai languages ${ }^{9}$ and Tibeto-Birman languages) as well as Na-Dene languages: Athapaskan, Tlingit and Hayda. For Sinitic languages and common Athapaskan re-constructions, whose value was known to Sapir before most of his contemporaries were aware of them, are given. These (re-)constructions of forms from Sinitic languages or older stages of Chinese languages were mostly adopted by Sapir from the well-known work of Karlgren (1923).

The material has attracted less attention and has not been published so far. In the past years or even decades the author of the present preliminary report was the only one who dealt with the Comparative dictionary of Indo-Chinese and Na-Dene in a detailed way (Knüppel 2012).

Some colleagues may argue that Sapir's materials lack value since today's state of research is much different from that of the 1920s. Furthermore, the genetic relationship of Na-Dene languages and Sino-Tibetan languages is discussed only in our times by individuals at the margin of academic activities, which seems to let the edition of these materials be a work of some anachronistic curiosity. Besides these objections, there is some importance of these materials for the history of comparative linguistics.

Besides Bengtson's (1994) article.

According to other allegations Athabaskan dictionary.

Kaye (1992: 282) gives the shelf mark "497-3, B 63c, Na $20 a .3$ (Part 2 - Film 1324)".

6 The title was given to the materials of the fourth "volume" of the comparative dictionary in the APS library to determine this material in bibliographical sense. The term "Indo-Chinese" was used by Bengtson (1994: 208) in the context of his explanation based on the content (in 1920). 1885-1944.

8 Cf., for example, Shafer (1952).

9 During the time of compilation of Sapir's dictionary the Thai languages were assigned to the Sino-Tibetan (or Indo-Chinese) languages, or at least the affiliation to this language family was not disputed to a large extent. 
Sapir's research relating possible genetic relationships of Na-Dene languages with the Sino-Tibetan language family was the most extensive attempt for proving the evidence of this kind of relationship. No former work on Na-Dene languages had been based on comparable material and had been of interest to researches active at the time. Sapir, for example, included records from Yeniseian languages in his comparisons, ${ }^{10}$ which is of some interest against the background of today's researches regarding Na-Dene-Yeniseian comparisons (irrespective of whether one believes in such a macro-family or not). In addition to this, Sapir was one of the first scholars who worked with reconstructions regarding the question of distant genetic relationships of Na-Dene languages. Till his research, various linguists and ethnographers commonly used lexical as well as semantic comparisons (occasionally by inclusion of phonology and morphology) and sometimes root-etymologies for these purposes. Besides, the mentioned article (Sapir 1915) presented the most extensive compilation of common Athapaskan (re-)constructions.

The aspired projects' aim is a commented critical edition of the complete Comparative dictionary of Indo-Chinese and $\mathrm{Na}$-Dene with the perspective of an edition of the remaining materials of Sapir's Comparative Na-Dene dictionary. The first volume of the edition should comprise a complete comparison of Sino-Tibetan and Na-Denean material, accompanied by an introduction, annotations and a full register of compared forms. In the introduction conditions of the development of this work will be ascertained and the comparisons undertaken by Sapir will be assessed as far as the contemporary state of research allows for this. The edition will follow the standards of scientific edition of historical documents of historically evidenced language materials as well as ethnographic materials as it was carried out in the volumes of the series "Quellen zur Geschichte Sibiriens und Alaskas aus russische Archiven" " "Sources on the history of Siberia and Alaska in Russian archives"], in which accounting records of the research of participants of the Second Kamchatka expedition of such travellers as G.F. Steller, J.G. Gmelin, J.E. Fischer, G.F. Müller and others were edited. It means that the aim is a textual critical as well as historical contextualized edition with extensive technical remarks relating the state of preservation, formal character and composition of the manuscripts and typoscripts, indication of line breaks / word wraps, handwritten remarks and deletions (if possible as technical editorial remarks in footnotes).

\section{References}

Bengtson J.D. 1994. Edward Sapir and the "Sino-Dene" hypothesis. - Anthropological Science 102.3: 207-230.

Karlgren B. 1923. Analytic dictionary of Chinese and Sino-Japanese. Paris.

Kaye A.S. 1992. Distant genetic relationship and Edward Sapir. - Semiotica 91.3-4: 273-300. Knüppel M. 2012. Zu Edward Sapirs "Comparative dictionary of Indo-Chinese and NaDene”. - Journal of Oriental and African Studies 21: 41-57.

10 Knüppel (2012; 2017, esp. p. 354, n. 9). 
Knüppel M. 2017. Jenissejisch-sino-tibetische Anmerkungen bei Robert P. Austerlitz. Németh M., Podolak B., Urban M. (eds.). Essays in the history of languages and linguistics. Dedicated to Marek Stachowski on the occasion of his $60^{\text {th }}$ birthday. Kraków: 351-355. Przyluski J. 1924. Langues sino-tibétaines. - Meillet A., Cohen M. (eds.). Les langues $d u$ monde. Par un groupe de linguistes sous la direction. Paris: 361-384.

Sapir E. 1915. The Na-Dene languages. A preliminary report. - AmA 17: 534-558.

Shafer R. 1952. Athapaskan and Sino-Tibetan. - IJAL 18.1: 12-19. 